\title{
Ендогенне дихання як складова терапевтичних вправ для людей похилого віку з пневмонією, спричиненою Covid-19 (на прикладі використання апарата Фролова)
}

\author{
УдК 616.12-039-089.8:615.825
}

\section{Г. С. Ільницька' ${ }^{1}$ Н. О. Зелененко ${ }^{1}$, С. В. Ільницький², I. В. Козєєв ${ }^{2}$}

${ }^{1}$ Національний фармацевтичний університет, Харків, Україна

${ }^{2}$ Харківський національний педагогічний університет ім. Г. С. Сковороди, Харків, Україна

Резюме. Мінімізація тяжкого перебігу коронавірусної інфекції для людей, що входять до групи ризику, і реабілітація після перенесеного захворювання є важливим фактором. У ході наукового пошуку, швидкого аналізу отриманих знань створюються клінічні рекомендації, удосконалюються підходи до діагностики, розробляються й удосконалюються методики респіраторного підтримання, але до сьогодні немає чітких і доведених алгоритмів лікування. Мета. Вивчити вплив ендогенного дихання на можливості респіраторної системи, використовуючи апарат Фролова як безпечний спосіб лікування та реабілітації. Методи. Аналіз і систематизація науково-методичної літератури та документальних матеріалів; логіко-теоретичний аналіз, спостереження, опитування, методи математичної статистики. Результати. Виявлено позитивну динаміку респіраторної системи. Отримані результати дозволили встановити рівень функціонального стану респіраторної системи. Експериментально доведено позитивний вплив ендогенного дихання на можливості респіраторної системи.

Ключові слова: фізична терапія, пневмонія, терапевтичні вправи, ендогенне дихання.

Endogenous respiration as a component of therapeutic exercises for the elderly with pneumonia caused by Covid-19 (on the example of using the Frolov apparatus)

H. S. Ilnytska ${ }^{1}$, N. O. Zelenenko', S. V. Initskyi' ${ }^{2}$, I. V. Kozeiev ${ }^{2}$
${ }^{1}$ National University of Pharmacy, Kharkiv, Ukraine
${ }^{2}$ H. S. Skovoroda Kharkiv National Pedagogical University, Kharkiv, Ukraine

Abstract. There is the minimization of the risk of severe coronavirus infection for people at risk, and rehabilitation after the disease is an important factor in the course of the scientific research, rapid analysis of gained knowledge, clinical guidelines are created, approaches to diagnosis are improved, methods of respiratory support are developed and improved. However, today there are no clear and proven treatment algorithms. Objective. To study the influence of endogenous respiration on the respiratory system capacities, using the Frolov apparatus as a safe method of treatment and rehabilitation. Methods. Analysis and systematization of scientific and methodical literature and documentary materials; logical-theoretical analysis, observations, surveys, methods of mathematical statistics. Results. Positive dynamics of the respiratory system was revealed. The findings allowed establishing the level of the respiratory system functional state. The positive effect of endogenous respiration on the respiratory system capacities has been experimentally proved.

Keywords: physical therapy, pneumonia, therapeutic exercises, endogenous respiration. 
Постановка проблеми. Наприкінці 2019 р. людство зіткнулося з новим, невідомим раніше вірусом 3 роду коронавірусів. Вчені всіх країн об'єдналися для вивчення його властивостей i особливостей перебігу захворювання, що викликані ним, якому ВООЗ присвоїла офріційну назву COVID-19 (Coronavirus disease 2019). Цей вірус характеризується, крім високої контагіозності, швидким розвитком двосторонньої пневмонії, що супроводжується дихальною недостатністю, гострим респіраторним дистрес-синдромом, смертністю частіше в осіб похилого віку, які мають супутню патологію. Нової інформації про перебіг цього інфекційного захворювання 3 кожним днем стає все більше, в тому числі і нової симптоматики. Наразі доведено, що люди 3 сильним імунітетом можуть бути безсимптомними носіями вірусу (46 \%) або переносити легку форму захворювання, яке протікає як звичайна ГРВІ [12]. У 15 \% випадків захворювання протікає набагато складніше з розвитком пневмонії різного ступеня тяжкості, а в $5 \%$ спостерігається несприятливий результат [14].

Важливим фрактором $є$ мінімізація ризику тяжкого перебігу коронавірусної інфекції для людей, що входять до групи ризику, і реабілітація після перенесеного захворювання. Особливостями вірусу $€$ його схильність до епітеліальних клітин верхніх і нижніх дихальних шляхів, а також кишечнику і сечовидільної системи. Вірус найчастіше передається повітряно-крапельним шляхом, рідше контактно-побутовим від хворої людини. Основні клінічні симптоми COVID-19це лихоманка, сухий кашель, відсутність нюху, утруднене дихання, біль у м'язах та суглобах, виражена слабкість. У більш важких ситуаціях вірус ушкоджує епітеліальні клітини дрібних бронхів, альвеол, альвеоло-капілярну мембрану - ті структурні відділи легень, де відбувається газообмін, внаслідок чого у людей розвивається двобічна вірусна пневмонія різного ступеня тяжкості [13].

Особливостями пневмонії при тяжкому перебігу $€$ некардіогенний набряк легенів (гострий респіраторний дистрес-синдром), що призводить до вираженого зниження кисню в крові, спазму судин і утворення тромбів та, як наслідок, поліорганної недостатності. Якщо у хворої людини хороший імунітет і $€$ резервні можливості організму, вірусна пневмонія протікає у неважкій формі і добре піддається медикаментозному лікуванню. Важкі фрорми пневмонії вимагають проведення ШВЛ і стаціонарного лікування у відділеннях реанімації та інфекційних відділеннях $[13,14]$.
Особливістю коронавірусу є його властивість викликати зниження рівня лімфоцитів у крові, що призводить до вираженої імунодепресії і приєднання бактеріальних та грибкових мікроорганізмів, що обтяжує перебіг захворювання [16]. На основі досвіду китайських і європейських лікарів фахівці виділили групи ризику, тобто людей, у яких більше шансів перенести важку форму COVID-19. Це люди старші 65 років, які страждають на серцево-судинні захворювання, цукровий діабет, онкологічні захворювання, а також хронічні бронхо-легеневі захворювання [13].

Пневмонія - стрес для організму. Легенева тканина після неї відновлюється протягом року. У цей час особливо важливо зміцнити імунітет і відновити резервні можливості організму [11]. Багато фрахівців прогнозують завершення пандемії у найближчий час [14]. Імовірно, що після перенесеного важкого перебігу захворювання у пацієнтів може сорормуватися незворотний легеневий фріброз, тому всім, хто переніс це захворювання, буде необхідна реабілітація. Знизити ризик важкого перебігу хвороби можна, дотримуючись профілактики, а також використовуючи засоби фрізичної терапії у вигляді терапевтичних заходів, дихальних вправ і лікувальної гімнастики, в тому числі з використанням дихальних тренажерів. До них належать:

1. Процедури, які сприяють зміцненню імунітету, зняттю запалення, поліпшенню циркуляції крові і газообміну:

- азотно-кремнієві ванни показані при санаторному лікуванні і рекомендовані тим, хто переніс пневмонію. Сьогодні вчені досліджують оксид азоту та його використання для насичення крові киснем. Властивості його давно застосовують 3 метою лікування різних судинних захворювань. Також азотно-кремнієві ванни зміцнюють імунітет і мають протизапальну дію [5];

- унікальний метод респіраторної медицини інтрапульмонарна перкусійна вентиляція легень. Під час процедури спеціальний апарат через відкритий дихальний контур подає повітря під невисоким тиском невеликими об'ємами (перкусія), не ушкоджуючи легені. Це дозволяє розправити ушкоджену альвеолу і поліпшити насичення крові киснем. Після вентиляції краще відходить мокротиння й очищуються бронхи $[7,8]$;

- кліматотерапія. Повітря, насичене аероіонами і фрітонцидами хвойного лісу, - найпотужніший лікувальний фрактор для легень. Прогулянки у лісі, дозована скандинавська ходьба допоможуть відновитися після захворювання [6];

- озонотерапія має противірусну, бактерицидну, фрунгіцидну дію, покращує обмінні процеси 


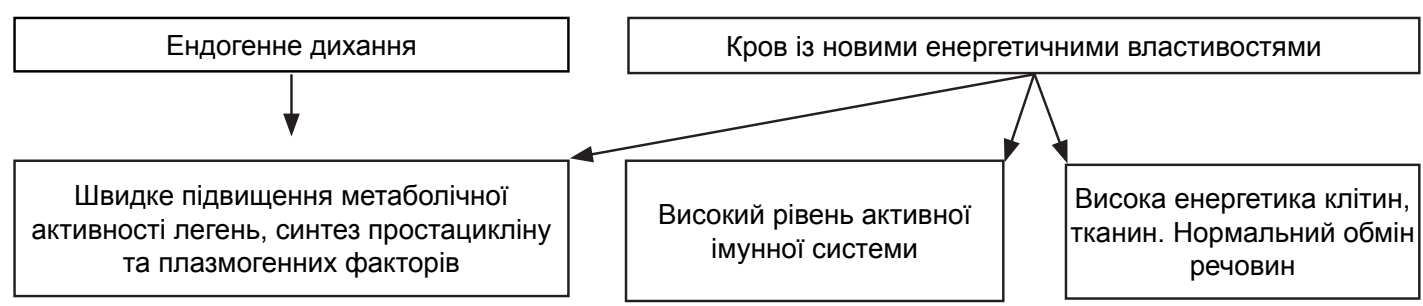

Рисунок 1 -

Основний механізм дії ендогенного дихання в усіх клітинах організму, є потужним антиоксидантом [6];

- сильвінітова спелеотерапія, гіпокситерапія, голкорефрлексотерапія, загартовування в лазнях і душах, фрізіотерапія, грязьові аплікації, інгаляції, фрізичні вправи [10].

2. Дихальна та звукова гімнастика. У повсякденному житті ми використовуємо тільки $30 \%$ обсягу легень. Середні і нижні відділи не беруть участі в газообміні і служать додатковим резервом $[4,15]$. Для того щоб поліпшити газообмін і зміцнити дихальну мускулатуру, необхідно регулярно займатися дихальною гімнастикою: розвивати дихання за допомогою апарата Фролова, дихати за методикою Стрельникової, виконувати вправи для м'язів плечового пояса. При COVID-19 строго не рекомендується надування повітряних кульок.

У ході наукового пошуку, швидкого аналізу отриманих знань створюються клінічні рекомендації, удосконалюються підходи до діагностики, розробляються й удосконалюються методики респіраторного підтримання, але до сьогодні немає чітких і доведених алгоритмів лікування [13, 14, 16].

Мета дослідження - вивчити позитивний вплив ендогенного дихання на можливості респіраторної системи, використовуючи апарат (тренажер) Фролова як безпечний спосіб лікування та реабілітації.

Методи дослідження: аналіз і систематизація науково-методичної літератури та документальних матеріалів; логіко-теоретичний аналіз, спостереження, опитування, методи математичної статистики.

Результати дослідження та їх обговорення. У дослідженні взяли участь 15 осіб 50-60 років, які перебували на позалікарняному лікуванні у післягострому періоді з діагностованою пневмонією, спричиненою вірусом SARS-CoV. Усі учасники надали згоду на участь в експерименті. Дослідження та тестування проводили дистанційно із застосуванням технологій відеотрансляції, дослідження фрункціонального стану - за допомогою проби Штанге [1, 2].

Одним із поширених захворювань легень, яке $\epsilon$ найбільш частою причиною смерті, $€$ пневмо- нія. Антибактеріальна терапія дозволяє зупинити запалення, але відновлення дихальної функції відбувається протягом більш тривалого часу [9].

Окрім медикаментозної терапії, при лікуванні захворювань легень з давніх часів застосовують різновиди дихальних гімнастик, уже майже п'ятдесят років з'являються різні дихальні тренажери [7, 8]. Вивчаючи ринок існуючих тренажерів, варто відзначити тренажер Фролова, який значно розширює лікувальні можливості. Він давно апробований і застосовується для поліпшення функції легень, але, на жаль, забутий, оскільки був популярний у нашій країні 15 років тому. Вважаємо перспективним його застосування в реабілітації осіб, які перенесли вірусну пневмонію. Винахідник тренажера В. Ф. Фролов дав початок безмедикаментозному лікуванню зворотних запальних захворювань легень і їх профрілактиці. Шкідливий вплив і ускладнення виключені. Основний механізм дії ендогенного дихання представлено на рисунку 1.

Дослідження доводять, що до 80 \% продуктів метаболізму виводяться 3 організму людини через легені, тобто за рахунок дихання [3]. Крім того, респіраторна система $є$ другою за важливістю системою людського організму, регулює кислотно-лужний баланс, видаляючи надлишки вуглецю. Ці процеси дуже важливі при захворюванні, особливо на вірусні інфекції, оскільки потрібно не тільки вивести з організму продукти життєдіяльності патогенних мікроорганізмів, а й відновити нормальний баланс [12].

Завдяки чергуванню вдихів 3 негативним тиском і видихів з підвищеним тиском відбувається якісний мікромасаж легень, який неможливо виконати за допомогою іншої технології. Дихальний тренажер є оригінальним портативним пристроєм, призначеним для проведення дихальних вправ з метою профрілактики і лікування різних захворювань, підвищення адаптаційних можливостей організму (рис. 2).

За допомогою тренажера можна здійснювати ефективне зволоження дихальних шляхів, використовуючи різні водорозчинні й олійні речовини для поліпшення відкашлювання мокроти, розрідження іï та зменшення бронхоспазму. Дихальний тренажер Фролова дозволяє проводити 
Рисунок 2 -

Апарат Фролова

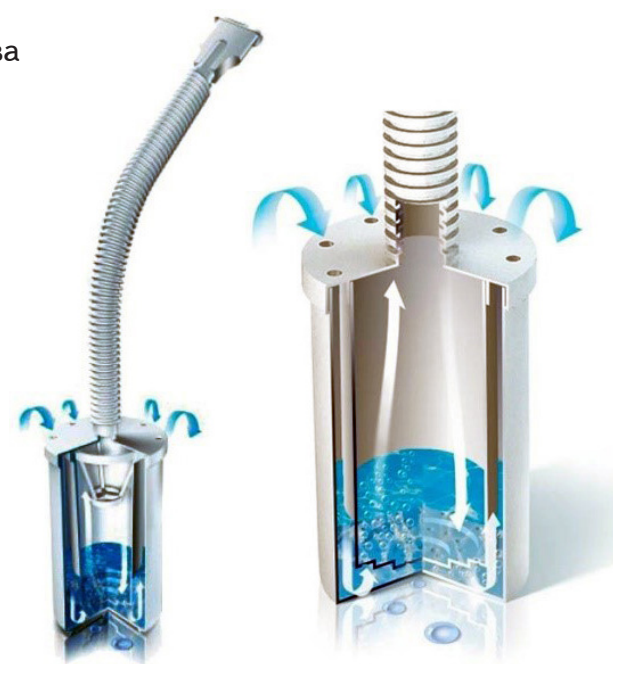

тренування дихальної мускулатури зі створенням опору як у фразі вдиху, так і видиху, поліпшувати обмін речовин органів і тканин у режимі так званого «адаптаційного дихання», що забезпечує розвиток адаптивних фрізіологічних реакцій організму в умовах помірно підвищеної концентрації вуглецю і контрольованого зниження вмісту кисню у вдихуваному повітрі.

\section{Механізм лікування пневмонії за допомогою апарата Фролова}

1. Діафрагмальне дихання - активне скорочення діафрагмального м'яза (розділяє грудну і черевну порожнини). Дозволяє забезпечити максимальне включення легеневої тканини в дихальний акт, збільшуючи дихальну поверхню. Діафрагмальний (черевний) тип дихання дозволяє регулювати внутрішньогрудний і внутрішньочеревний тиск. Регуляція першого створює оптимальні умови для роботи серцево-судинної і бронхо-легеневої систем. Регуляція другого, створюючи масажний ефект на органи черевної порожнини, сприяє більш активному їх кровонасиченню, з одного боку, а з іншого - посиленню видільної функції, яка має очисний ефект.

2. Підвищення опору на вдиху і видиху (за рахунок зміни об'єму води, що заливається в апарат) викликає збільшення позитивного тиску на видиху і негативного тиску на вдиху. Тиск на видиху спричиняє розширювальний ефект на бронхи, що значно покращує вентиляцію легень і сприяє підвищенню концентрації кисню в крові, органах і тканинах. Підвищення опору на вдиху приводить до наростання негативного тиску в бронхах і легенях, що активує роботу келихоподібних і вієподібних клітин (у перших утворюється секрет, другі мають властивість активно просувати секрет з бронхіального простору), сприяючи тим самим очищенню бронхів і легень від слизу і мокротиння. Крім того, підвищення негативного тиску на вдиху значно посилює циркуляцію крові в бронхіальних і легеневих капілярах, що покращує не тільки газообмін у легеневій тканині, а й активує велику кількість інших її функцій.

3. Барботація - бульбашки повітря у внутрішній камері апарата виконують функцію зволоження вдихуваного повітря, що можна використовувати і для інгаляції лікарських препаратів, у тому числі противірусних.

На першому етапі дослідження було виконано пошук людей з діагностованою пневмонією, які мали ці тренажери або могли їх собі дозволити, використовуючи інтернет-технології.

Проведене попереднє дослідження на другому етапі довело, що функціональний стан кардіореспіраторної системи тестованих знаходиться на незадовільному та задовільному рівнях, що свідчить про нестійкість організму до гіпоксії. Проведення проби Штанге до експерименту виявило такі результати: незадовільно мали $60 \%$ тестованих, задовільно - $35 \%$, добре - $5 \%$ осіб.

На третьому етапі було проведено експеримент, під час якого тестовані протягом 14 днів займалися тренуванням дихання з використанням апарата Фролова, на 1-му тижні - тривалістю по 15 хв на день, на 2-му тижні - по 20 хв на день. Stop-сигналами для проведення занять 3 немедикаментозного лікування пацієнтів 3 коронавірусною пневмонією в умовах домашньої ізоляції були: температура вище $38{ }^{\circ} \mathrm{C}$, посилення задишки, підвищення ЧСС більше 50 \% вихідної величини, відчуття стиснення в грудях, блювота, запаморочення, головний біль, помутніння свідомості, пітливість, неспроможність тримати баланс.

На цьому етапі також було проведено контрольне тестування з метою виявлення позитивної динаміки респіраторної системи з повторним проведенням проби Штанге (табл. 1).

Висновки. Результати дослідження показали позитивну динаміку респіраторної системи після впровадження дихання за допомогою апарата Фролова, покращився фрункціональний стан респіраторної системи. В усіх тестованих збільшився час затримки дихання під час вдиху, про що свідчать оцінки стану респіраторної системи до і після проведення експерименту. Це характеризує здатність організму протистояти нестачі кисню, i, отже, пацієнти стали краще переносити виконання дихальних вправ.

У ході дослідження було встановлено рівень фрункціонального стану респіраторної системи (на вдиху). Також експериментально було дове- 
ТАБЛИЦЯ 1 - Результати проведення проби Штанге до і після експерименту

\begin{tabular}{|c|c|c|c|c|}
\hline Тестований & Результат до експ. (хв, с) & Результат після експ. (хв, с) & Оцінка стану до експерименту & після експерименту \\
\hline 1 & $0: 21$ & $0: 35$ & незадовільно & задовільно \\
\hline 2 & $0: 32$ & $0: 47$ & задовільно & добре \\
\hline 3 & $0: 15$ & $0: 32$ & незадовільно & задовільно \\
\hline 4 & $0: 30$ & $0: 45$ & задовільно & добре \\
\hline 5 & $0: 19$ & $0: 34$ & незадовільно & задовільно \\
\hline 6 & $0: 37$ & $0: 51$ & задовільно & добре \\
\hline 7 & $0: 20$ & $0: 40$ & незадовільно & задовільно \\
\hline 8 & $0: 25$ & $0: 39$ & незадовільно & задовільно \\
\hline 9 & $0: 13$ & $0: 41$ & незадовільно & добре \\
\hline 10 & $0: 42$ & $1: 05$ & добре & відмінно \\
\hline 11 & $0: 17$ & $0: 40$ & незадовільно & задовільно \\
\hline 12 & $0: 31$ & $0: 55$ & задовільно & добре \\
\hline 13 & $0: 39$ & $1: 12$ & задовільно & відмінно \\
\hline 14 & $0: 11$ & $0: 39$ & незадовільно & задовільно \\
\hline 15 & $0: 17$ & $0: 47$ & незадовільно & добре \\
\hline
\end{tabular}

дено позитивний вплив ендогенного дихання на можливості респіраторної системи, використовуючи апарат (тренажер) Фролова як безпечний спосіб лікування та реабілітації.

\section{Література}

1. Андреева АД. Применение проб Штанге и Серкина для оценки адаптации организма человека к физическим нагрузкам [Application of Stange and Serkin's tests to assess the adaptation of the human body to physical loads]. Прорывные научные исследования как двигатель науки. 2017: 10-13

2. Авраменко IB. Оцінка змін функції зовнішнього дихання у пацієнтів після тяжкої негоспітальної пневмонії в динаміці протягом року [Assessment of changes in the function of external respiration in patients after severe pneumonia in the dynamics during the year]. Буковинський медичний вісник, 2016; 20 (2 (78): 9-15.

3. Большев АС, Сидоров ДГ, Игнатьев ПВ. Влияние показателей пробы Штанге на результаты выполнения испытаний комплекса ГТО [The influence of the Shtange sample indices on the results of the GTO test]. Сборник избранных статей по материалам научных конференций ГНИИ «Нацразвитие». 2018. 168-170.

4. Григус IM. Методологічні аспекти проведення фізичної реабілітації у хворих на хронічний бронхіт [Methodological aspects of physical rehabilitation of patients with chronic bronchitis]. Physical education, sport and health culture in modern society. 2012; 3 (19): 282-287.

5. Дзюблик ЯО. Особливості епідеміології негоспітальних інфекцій нижніх дихальних шляхів в Україні [Features of the epidemiology of community acquired infections of the lower respiratory tract in Ukraine]. Український пульмонологічний журнал. 2012; (4): 30-32.

6. Ільїна ВГ, Нікіпелова ОМ. Рекреаційні ресурси і курортологія: збірник методичних вказівок до семінарських занять (4) [Recreational resources and balneotherapy: a collection of guidelines for seminars ]. Одеса, 2011. $50 \mathrm{c}$.

7. Кучмин АН, Акимкин ВГ, Синопальников АИ. Диагностика, лечение и профилактика внебольничной пневмонии у военнослужащих МО РФ: метод. указания [Diagnosis, treatment and prevention of community-acquired pneumonia in servicemen of the MD of the RF]. Москва: ГВКГ им. Н. Н. Бурденко. 2010: 66.

annet487@gmail.com

Zelik0204@ukr.net
Перспективою подальших досліджень $\epsilon$ вивчення респіраторної системи під час видиху у такій самій категорії тестованих.
8. Майструк MI. Фізична реабілітація хворих на хронічне обструктивне захворювання легень: [монографія] [Physical rehabilitation of patients with chronic obstructive pulmonary disease]. Хмельницький, 2018. 340 c.

9. Мужичук ВО, Дугіна ЛВ, Без'язична ОВ. Фізична терапія при негоспітальній пневмонії [Physical therapy for community-acquired pneumonia]. Фізична реабілітація та рекреаційно-оздоровчі технології. 2020; 5(2): 72-75.

10. Островський ММ, \& Варунків О І. Особливості етіології, клінічного перебігу, діагностики та лікування негоспітальної пневмонії у осіб похилого віку [Features of etiology, clinical course, diagnosis and treatment of community-acquired pneumonia in the elderly]. Здоров'я України. Вересень. 2010: 37-39.

11. Фатуллаева ГА, Богданова ТМ. Пневмония - актуальная проблема медицины [Pneumonia is an urgent medical issue]. Международный студенческий научный вестник. 2018; 5 [Режим доступу] URL: http:// eduherald. ru/ru/article/view?id $=19158$

12. Шевченко АС, Шлемова МВ, Чернышева ИВ. Егорычева Е.В. Основы методики ЛФК при заболеваниях органов дыхания. Международный журнал экспериментального образования. 2014. 7(2). 89-90 [Режим доступу] URL: http://www.expeducation.ru/ru/article/view?id=5593.

13. Chen $\mathrm{N}$ et al. Epidemiological and Clinical Characteristics of 99 Cases of 2019-Novel Coronavirus (2019-nCoV) Pneumonia in Wuhan, China. 2020.

14. European Commission. Novel coronavirus 2019-nCoV [Режим доступу] URL: https://ec.europa.eu/health/coronavirus_en

15. Kozina ZL, Kozin VY, lermakov SS, Krzheminski M, Lahno EG, Bazyilyuk TA, Initskaya AS. Sistema sovremennyih tehnologiy integralnogo razvitiya ukrepleniya zdorovya lyudey raznogo vozrasta: monografiyadlya [System of modern technologies of integral development and health promotion of people of different ages: monograph]. ZL Kozina Eds. Kharkiv--Radom: Tochka. 2017.

16. Frieman MB, Jahrling PB. Middle East Respiratory Syndrome and Severe Acute Respiratory Syndrome: Current Therapeutic Options and Potential Targets for Novel Therapies. Drugs. 2017; 77 (18): 1935-1966.

17. https://www.frolov.co 